\title{
小児腎血管性高血圧に対する異所性自家腎移植の経験
}

$\begin{array}{cccccc} & \text { 門 } & \text { 脇 } & \text { 照 } & \text { 雄 } \\ & \text { 金 } & \text { 子 } & \text { 茂 } & \text { 男 } \\ & \text { 近畿大学医学部泌尿器科学教室 } & \text { 井 } & \text { 口 } & \text { 正 } & \text { 典 } \\ & \text { (主任: 栗田孝教授) } & & \text { 光 } & \text { 二 } \\ & & \text { 秋 } & \text { 山 } & \text { 隆 } & \text { 弘 } \\ & \text { 八 } & \text { 竹 } & & \text { 直 }\end{array}$

\section{AUTOTRANSPLANTATION OF THE KIDNEY IN THE TREATMENT OF THE RENOVASCULAR HYPERTENSION IN CHILD}

\author{
Teruo Kadowaki, Shigeo Kaneko, Masanori Iguchi, Koji Minami, \\ Takahiro Akiyama and Sunal Yachiku \\ Department of Urology, Kinki University School of Medicine
}

(Director: Prof. Takashi Kurita)

\begin{abstract}
Hypertension of renovascular origin is potentially a surgically correctable condition. In children, the results of primary repair of the affected renal artery or bypass graft have been far less satisfying, Most attempts at revascularization have ended in thrombosis of the repaired vessel and subsequent nephrectomy. The high rate of failure of revascularization in children has been attributed to technical problems due to the small size of the involved vessels and the growth of the child. Autotransplantation is a safe and reasonable procedure in the management of childhood renovascular hypertension. We reported herein a twelve-year-old girl with stenosis of the left renal artery caused by aortitis syndrome who underwent such a procedure.
\end{abstract}

\section{緒言}

小児期に执いても高血圧を呈する疾患は少なくない が，腎血管性高血圧の報告は成人に比し少なく稀な疾患 とされている.本症は外科的治療により治癒ないしは改 善が期待出来るものであり，そのうち異所性自家腎移植 術は 1 次的汇施行する場合でる autograft あるいは dacrongraft 等の腎血行再建術が不成巧に終つた後に 2 次的 に施行する場合でも好成績を掞さめているようである。 最近我々の教室に沶いて大動脈炎症候群に合併した小児 腎血管性高血圧患者に対する異所性自家腎移植術を経験 したので若干の文献的考察とともにその概要を報告す る。

\section{症例}

患者: 12 歳, 女子

主訴: 失神発作, 頭痛.

家族歴：既往：特記すべきことなし。
現病歴 : 昭和50年 10 月, 偏頭痛を自覚し学校より㷌 宅. その後意識不明となり某院へ緊急入院す。入院時血 圧は208/130mmHg であつた。

2 日後に覚醒するも頭重感と視力減退が認められたた め精查目的にて当院第 1 内科入入院となる.入院時血圧

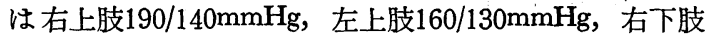
$160 / 110 \mathrm{mmHg}$ ，左下肢226/156mmHg であり，左橈骨動 脈の拍動は極めて微弱であつた，入院後各種降圧剤を使 用し，血圧は右上肢で160/120 mmHg 前後とやや安定す るも払張期高血圧の傾向は持続 乙，血管造影時 に再度 失神発作が出現し約 20 時間意識消失状態となつた。その 時に施行した脳波検查は，高血压性脳症と診断された。 以上のごとき経過により大動脈炎症候群に合併した腎血 管性高血圧症の疑いにて昭和51年 1 月泌尿器科に転科し た。

現症：体格，栄養ともに良好で，眼䀫結膜に貧血を認 
めない，胸部打聴診にて心の左方拡大を認め, 第 2 音の 克進と大動脈弁閉鎖不全を思わせる収縮期雑音を聴取し た、腹部血管雑音は聴取しなかつた。腹部は平担, 軟で 肝, 脾, 腎は触知せず。病的反射, 浮腫は認めない。

諸検查成績：血沈 1 時間值 $20 \mathrm{~mm}, \mathrm{RBC} 499 \times 10^{4}$, WBC 3, 400, Hb 13.4gm, Ht 39.0\%, 白血球分画 Band 12 , Seg. 10, Lym. 71, Mono. 2, Eos. 2, Bas. 3, TP. 6.7g/dl, $\gamma$-glob. 15.9\%, GOT 24, GPT 10, Al-p 137 U/L, LDH 184U/L, CPK 16U/L, BUN $9 \mathrm{mg} / \mathrm{dl}$, creatinine $0.6 \mathrm{mg} / \mathrm{dl}, \mathrm{Na} 141 \mathrm{Eq} / \mathrm{L}, \mathrm{K} 3.0 \mathrm{mEq} / \mathrm{L} \mathrm{Cl} 96 \mathrm{mEq} /$ L, Glucose $82 \mathrm{mg} / \mathrm{dl}$, Wa-R 陰性, ッベルクリン反応陽 性, 抗㤥抗休陰性, ASLO 1:833, CRP 陰性, RA 陰 性.

内分泌学的検查: 末梢静脈血 PRA は安静阶床時10.4 $\mathrm{ng} / \mathrm{ml} / \mathrm{h}, 2$ 時間起立歩行後 $13.5 \mathrm{ng} / \mathrm{ml} / \mathrm{h}$, 血清アルドステ ロン值 $95 \mathrm{ng} / \mathrm{dl}$, 血清アンギオテンシン II $190 \mathrm{pg} / \mathrm{ml}$ ，尿 中 VMA 3.8mg/day, 左右腎静脈 PRA 比2.8.

心電図所見 : 左室肥大を示す.

腿底所見: 両眼底ともに乳頭浮腫があり, 特に右腿底 には線状出血, 白斑などの所見とともに, 視野狭窄, 中 心暗点が認められた。

レ線学的所見：排泄性腎盂撮影 (Fig. 1) にて左督は

Fig. 1 Preoperative intravenous pyelogram demonstrates a disparity in the size of the kidney.

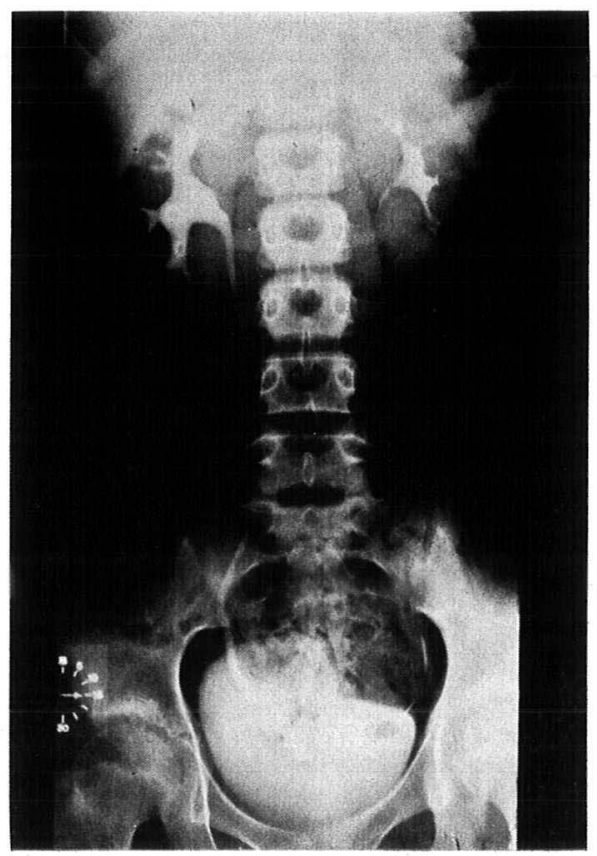

Fig. 2 Thoracic aortogram shows absent of left subculavian artery.

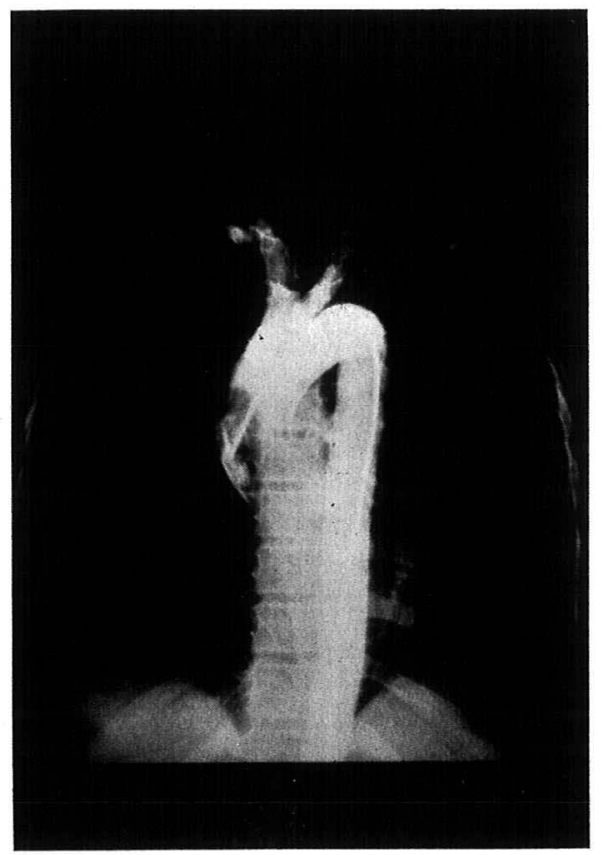

Fig. 3 Abdominal aortogram shows high grade stenotic lesions of left renal artery with poststenotic dilatation.

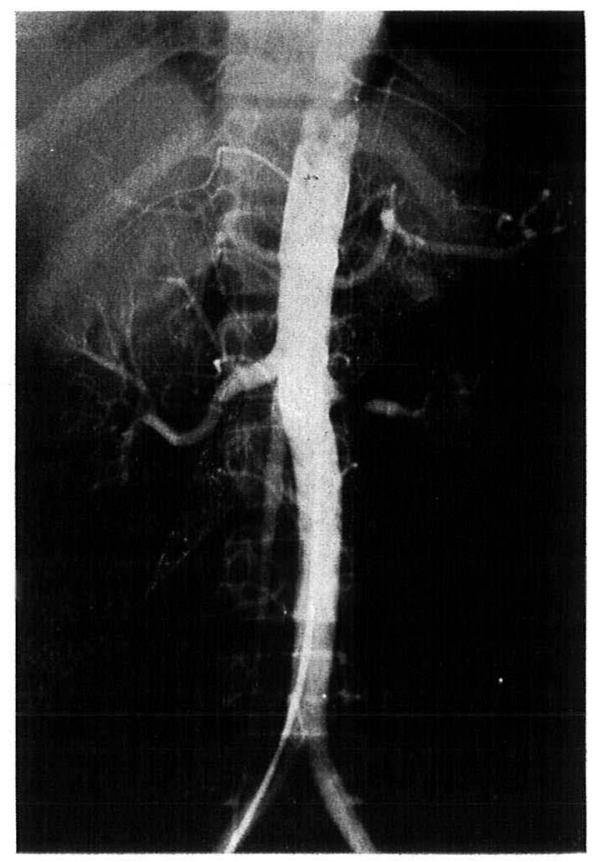


右腎に比し小さく, 造影不良の所見が得られ, 急速静注 法による腎盃撮影でも排泄遅延を認めた。胸部大動脈造 影 (Fig. 2) では左鎖骨下動脈は, 大動脈分伎部で完全 に閉塞し, 腹部大動脈造影 (Fig. 3) で左腎動脈は起始 部付近で $90 \%$ 以上の狭窄像を示した. ${ }^{131} \mathrm{I}$ にるレノグ ラムで左腎は L 型を呈し, 高度の虚血性変化と考兄られ た (Fig. 4)

Fig. 4 Preopeative renogram shows highly ischemic pattern of left kidney.

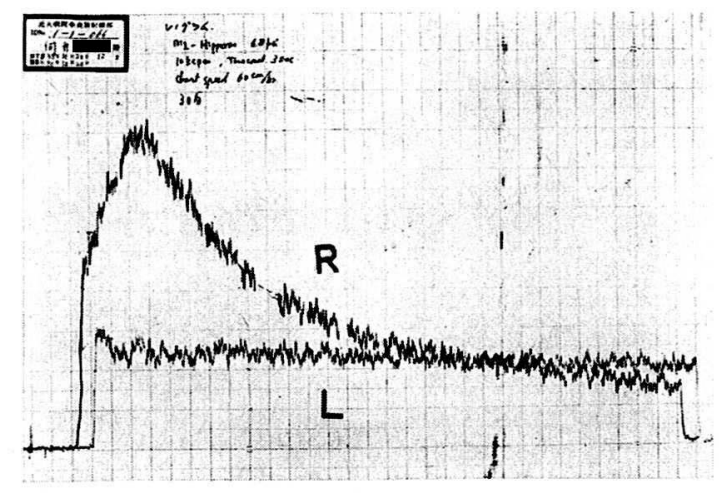

Fig. 5 Blood flow measurement of preoperation (rt) and postoperation (lt) demonstrates remarkable improvement after autotransplantation.

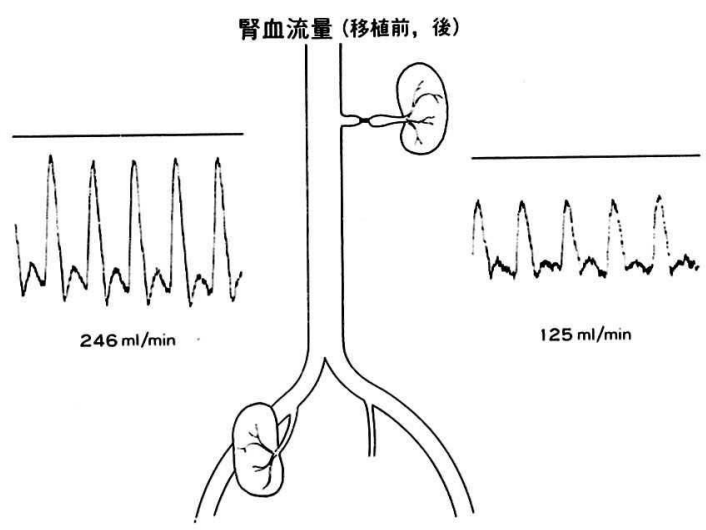

以上の諸検查結果より大動脈炎症候群に合併した左腎 血管性高血圧症と診断し, 昭和51年 1 月19日全身麻酔の もと, 左腎を右腸骨窩へ自家移植し, 腎動脈は内腸骨動 脈と端々吻合, 腎静脈は総腸骨静脈と端側吻合した。尿 管は paquin 法に従い膀胱尿管新吻合を行つた.

腎阻血時間は30分であり, 血流再開と同時に尿の排出 がみられた。術前および術中に抗凝固剤の使用は行つて いない，手術時に電磁流量計 (Fig. 5) およびドップラ
Fig. 6 Doppler flow pattern demonstrates significant increase of blood flow postoperation (under) than preoperation (upper).

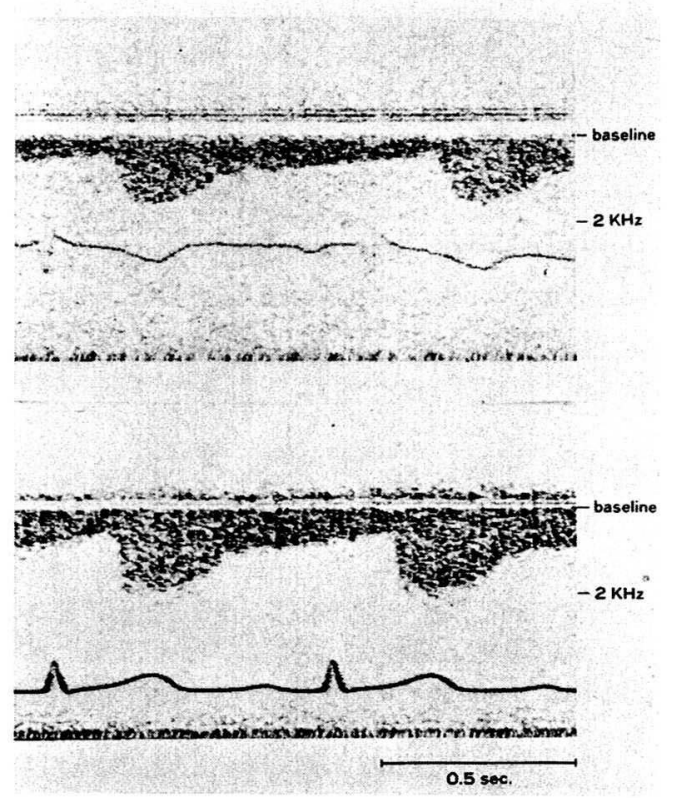

一（Fig. 6) を使用し腎血流の変化を測定してみた。 電磁流量計は, 日本光電製 multi-channel square wave electromagnetic flowmeter, プローブ番号392を使用しド ップラーは方向指示型超音波血流計（日立メディュ製 EUD-2 型）を用い，腎動脈にガス消毒された採触子を 直接接触させ最大音を検出, 記録した 後拡張部の血流量 $124.6 \mathrm{ml} / \mathrm{min}$ で移植後 $248 \mathrm{ml} / \mathrm{min}$ と 著明に増加し，ドップラーでも波形はII 型より I 型に変 り血流改善の所見が得られた

術後経過（Fig. 7)：血浆レニン活性值および血浆

Fig. 7

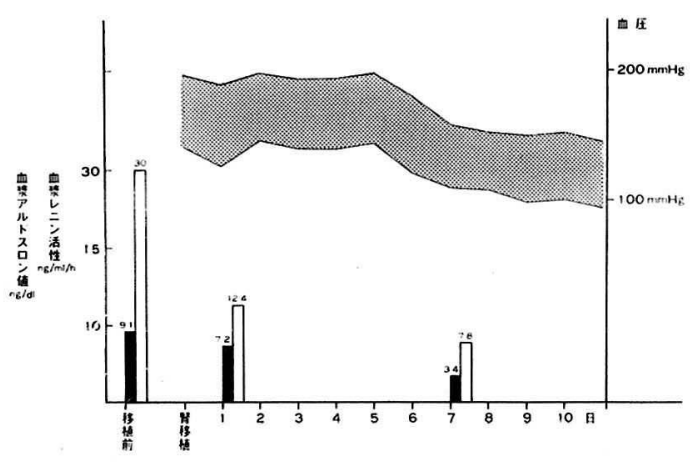


Fig. 8 Postoperative arteriogram at 4 weeks demonstrating a good anatomical results after autotransplantation with an increase in the size of the kidney.

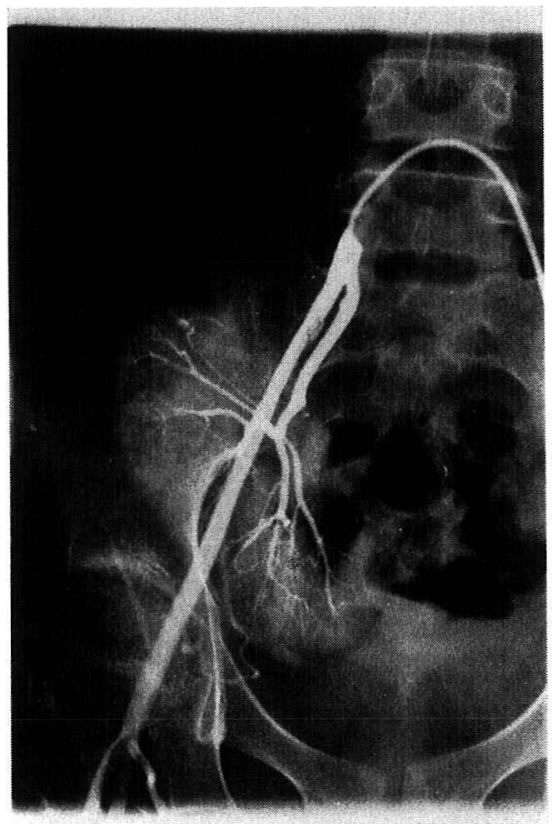

Fig. 9 Postoperative arteriogram at 10 months shows complete occulusion of the hypogastric artery.

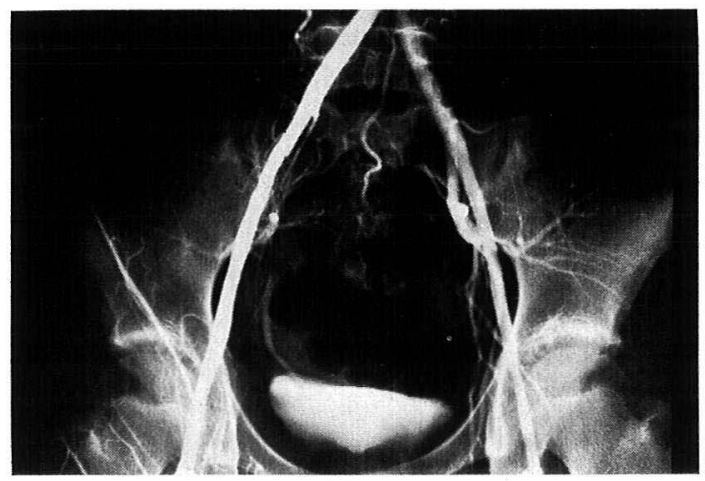

アルドステロン值は術後24時間目には著明に低下した が，血压はな特高值を続け6 日目より下降し始め 7 日目 以降血圧は右上肢で140/90 $\mathrm{mmHg}$ 前後に固定した。血 浆レニン活性值, 血浆アルドステロン值は術後 1 週間目 にほぼ正常域になつた。術後 4 週目の血管造影(Fig. 8) で移植腎機能は良好と思われ，血管に異常は認められな い，術後 9 カ月までは，降圧剂等の使用をせずに血圧
Fig. 10 Photomicropraph of the resected renal artery shows thickning of the media and intimal fibroplasia.

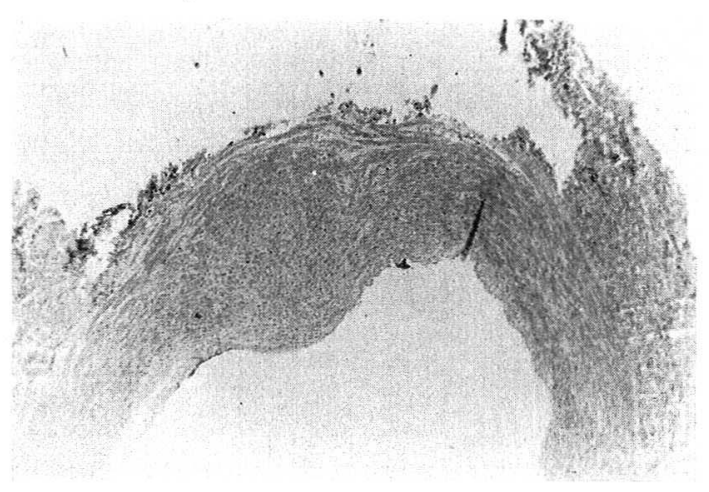

140/90mmHg 前後に安定し, 術前みられた眼底浮腫等 の所見拉よび偏頭痛の消失と極めて経過良好と思われ たが，10カ月頃より血压160〜170/100mm Hg と徐々に 上昇の傾向がみ々られ, 偏頭痛も出現し, 左橈骨動脈に加 充右橈骨動脈の拍動もほとんぞ触知出来なくなつた。術 後10力月目の血管造影（Fig.9）にて，総腸骨動脈は やや不整で大動脈炎の進行と考兵られる所見を呈し, 移 植腎機能の廃絶を認めた. 現在血圧およびCRP，血沈值 の変化を指標としながら各種降王剤と副腎皮質ホルモン 剤を投与し経過観察している。

組織学的所見 (Fig. 10) : 狭䇤部の腎動脈は内膜执よ び中膜の肥厚が軽度涩められ，筋線維の断裂も有する が，リンパ球の浸潤は殆んどなく巨細胞も認めなかつ た。この組織学的所見からは, 大動脈炎症候群とは断定 出来なかつた。

\section{考察}

小児期に物ける高血圧の特徵は，本態性高血圧の占め る割合が成人に比べ極めて少なく，小児高血圧症の $80 \%$ が 2 次性高血圧であると言わ机ている ${ }^{3)}$. そのらち腎血 管狭窄を原因とするものは，Still ら"集計によると 9 \%にあたる.大動脈炎症候群は, 大動脈と大動脈に近い 基幹動脈の特殊炎症とその洀痕収縮により, 狭窄や狭窄 前後の拉張を来たす疾患と定義され，自己免疫疾患之の 関係が指摘されているが5) その治療方法は未だ確立され たものはない.大動脈炎症候群と腎動脈狭窄の合僧率は, 上田 ${ }^{6)}$ の統計によると約 $20 \%$ に和よび，本邦に和ける腎 血管性高血圧症のらち，大動脈炎症候群に基因するもの は，日台 ${ }^{7}$ の文献上285例の集計によると30\%にのぼると 述べている，小児腎血管性高血圧症は，基本的には外科 
的治療の適応となる疾患であり ${ }^{87} 1939$ 年 Leadbetter and Burkland $^{9)}$ が患側腎摘除により，小児高血圧症を治癒せ しめた最初の報告をして以来, 成人の場合と同様本疾患 に対する根治手術として患腎摘除が多数行われてきた $か^{10)}$, 最近の本疾患に対する認識 の向上と血管外科の 進歩により, Autograft, Dacrongraft, Splenorenal Anas tomosis 等の腎血行再建術が試みられるようになり, Foster $ら^{11}$ の10年間 90 例の統計によると約 $80 \%$ の成功率 を扣さめている、しかしながら，小児に和ける腎血行再 建は血管径が小さいこと，まだ成長過程にあること等か ら成人に比しその成績は悪 ${ }^{12)}$, Coran and Schuster ${ }^{13)}$ は小児腎血管性高血圧症 6 例に腎摘除を行つたと報告 し, Kaufman $5^{3)}$ の集計によると, 少なくとも2/30症 例が 2 次的に腎摘除をらけていると述べている。したが つて小児期に和ける高血圧は, 出来るだけ内科的治療 によりその手術的操作の時期を遅らせるとの考光方もあ るが, 強度の狭窄がある場合は降圧剂により効果的に血 圧低下をみても, 腎血流量が減少する為か兄つて腎機能 が低下するとの報告もあり ${ }^{12)}$, 薬剤の副作用, 心肺機能 への負担を考慮すると内科的治療にも扮のずと限界があ る. Franklin $5^{14)}$ の502例の腎血管性高血圧患者に対す る手術成績をみると, 狭心症発作の既往をもつ患者と, もたない患者の手術死の危険性は約 3 倍と有意の差を認 ぬ, 心電図上扣よび胸部レ線上左室肥大の所見を有する 場合は1.5倍の危険性があつたと述べている，異所性自 家腎移植は，1963年 Hardy ${ }^{15)}$ が高位尿管損傷 に対し 施 行したのが最初であり, 腎血管性高血圧症に対する本術 式の成功例は1963年の Woodruf ${ }^{16)}$ の報告を初例とし, 以後本邦拈よび 欧米文献上約 50 例 ${ }^{17)}{ }^{23)}$ の報告にみられ るごとく適応徒例の選択に留意すればほとんど失敗例が なくわれわれの教室における同種腎移植の経験からみ ても，技術的には安全かつ確実な手術方法と考党られ る.

また基礎疾患である大動脈炎症堠群の病変が将来進行 する可能性があることから, 腎摘除は極力避けるべきで

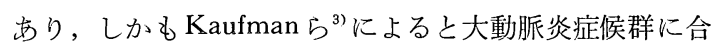

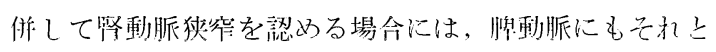
同程度の病変の波及を認めると述べている。以上の観占 よりわれわれの症例に対し, 異所性自家腎移植術を選び 施行した。本術式は腎血管性高血圧将, 特に小児の場合 には積極的に試みられるべきものと考える。しかしなが ら，本症例の場合は先にも述べたごとく手術そのもの は，ほぼ満足すべきであつたが，原疾患で西る大動脈炎
症候群の病変の進行を阻止出来ず結果として失敗に帰し たことから，CRP，血沈値を指標として術後慎重なる経 過観察の必要性を強調したい。

\section{結 語}

大動脈炎症候群に合併した12歳女子の腎血管性高血圧 症に対して, 異所性自家腎移植術を施行した。術後 10 力 月目までは, 良好なる結果が得られたが, その後, 基礎 疾患の病変進行のため, 移植腎機能の廃絶となつた。異 所性自家腎移植につき文献的考察を行らとともに本術式 の積極的な応用を推奨した。

（稿を終えるにあたり，ご校閲いただいた恩師栗田孝 教授に深謝致しまけ。尚本俩文の要旨は, 第26回泌尿器 科打部連命地方公で述べたもので节る。）

\section{文献}

1) 有馬正明, 佐川果郎, 高村 津, 浅生雅人, 林 等, 北畠顕, 松尾裕英, 園田孝夫：日泌尿会誌, $67: 231,1976$.

2) 有馬正明, 佐川史郎, 高羽津, 園田孝夫, 秋 山隆弘, 栗田 孝, 松尾裕英, 浅生雅人, 林 享, 北甶 顕, 仁村泰治 : 日超医諭文集, 2951, 1976.

3) Kaufman, J.J., Goodwin, W.E., Waiseman, J. and Gyepes, M.J.: Amer. J. Surg., 124, 149, 1972.

4) Still, J.L. and Cottom, D.: Arch. Dis. Child., 42, 34, 1967.

5）上田英雄：日本臨床， $26 ： 197,1968$.

6) 上田英雄, 伊藤㦑, 武田恕直, 杉浦昌也, 斉 藤嘉美, 諸岡成徳: 最新医学, $23: 1730,1968$ 。

7) 日台英雄, 堀内満水雄, 和田達雄, 吉田 悟, 尾 上正明, 石橋信 : 日泌尿会誌, $64: 1042,1973$.

8) Fry, W.T., Calvin, B.E., Stanley, J.C., Brink, B. and Mich, A.A.: Arch. Surg., 107, 692, 1973.

9) Leadbetter, W.F. and Burkland, C.E.: J. Urol., 39, 611, 1938.

10) Smith, H.W.: J. Urol., 76, 685, 1956.

11) Foster, J.H., Dean, R.H., Pinkerton, J.A. and Rhamy, R.H.: Ann. Surg., 177, 755, 1973.

12) Sinaiko, A., Najarian, J., Michael, A.F. and Mirkin, B.L.: J. Pediat., 83, 409, 1973.

13) Coran, A.G. and Schuster, S.R.: Surgery, 64, 672, 1968.

14) Franklin, S.S., Young, J.D., Maxwell, M.H., Foster, J.H., Palmer, J.M., Cerny, T. and Varady, P.D.: JAMA, 231, 1148, 1975.

15) Hardy, J.D.: JAMA, 184, 97, 1963.

16) Woodruf, M.F.A., Doig, A., Donald, K.W. and Nolan, B.: Lancet, 1, 433, 1966.

17) Serrallach-Milla, N., Paravinsini, J., Mayou- 
Valls, P., Alberti, J., Casellas, A. and NollaPanadis, J.: Lancet, 2, 1130, 1965.

18) Marshall, V.F., Whistell, J., McGovern, J.H. and Miscall, B.B.: JAMA, 196, 138, 1966.

19）中山宏, 平田弘, 真崎喜二郎; 永芳弘之: 皮之泌, $30: 594,1967$.

20) 中西純造, 前川正信, 甲野三郎, 服部 洋: 泌 尿紀要, $15: 285,1969$.
21) Clunie, G.T.A., Murphy, K.T., Lukin, L., Nicoll, P. and Marsden, R.T.H.: Surgery, 69, 326, 1971.

22) Hodges, C.V., Lawson, R.K., Pearse, H.D. and Stranburg, C.O.: J. Urol., 110, 20, 1973.

23) Belzer, F.O., Salvatierra, O., Palvinskas, A. and Stoney, R.T.: Ann. Surg., 182, 456, 1975. (1977年 1 月14日受付) 